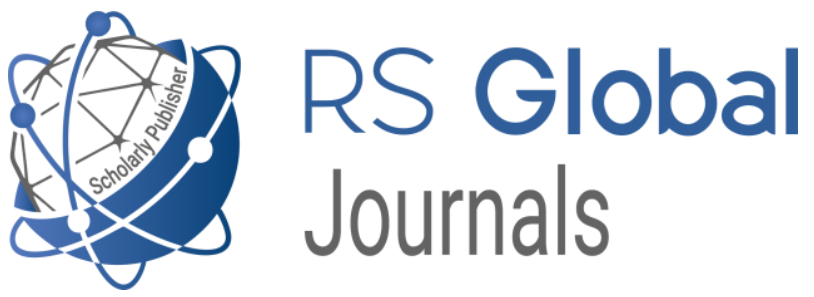

Scholarly Publisher RS Global Sp. z O.O. ISNI: 0000000484952390

Dolna 17, Warsaw, Poland 00-773

Tel: +48226022703

Email: editorial_office@rsglobal.pl

\begin{tabular}{ll} 
JOURNAL & Science Review \\
p-ISSN & $2544-9346$ \\
\hline e-ISSN & $2544-9443$ \\
\hline PUBLISHER & RS Global Sp. z O.O., Poland
\end{tabular}

ARTICLE TITLE

CONDITION OF BONE TISSUE IN PREGNANT WOMEN WITH DISEASES OF THE CARDIOVASCULAR SYSTEM ON THE BACKGROUND OF ANTICOAGULANT PREVENTION

$\operatorname{AUTHOR}(\mathbf{S})$

V. Medved, T. Savka

V. Medved, T. Savka. (2021) Condition of Bone Tissue in

ARTICLE INFO Pregnant Women with Diseases of the Cardiovascular System on the Background of Anticoagulant Prevention. Science Review. 1(36). doi: 10.31435/rsglobal_sr/30012021/7379

DOI https://doi.org/10.31435/rsglobal_sr/30012021/7379

RECEIVED

29 November 2020

ACCEPTED

17 January 2021

PUBLISHED

23 January 2021

LICENSE

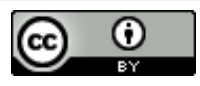

This work is licensed under a Creative Commons Attribution

4.0 International License.

(C) The author(s) 2021. This publication is an open access article. 


\title{
CONDITION OF BONE TISSUE IN PREGNANT WOMEN WITH DISEASES OF THE CARDIOVASCULAR SYSTEM ON THE BACKGROUND OF ANTICOAGULANT PREVENTION
}

\author{
V. Medved, Professor. Head of department of internal pathology pregnants, State Institution "Institute \\ of Pediatrics, Obstetrics and Gynecology named academic Elena M. Lukyanova of National Academy \\ of Medical Sciences of Ukraine" Kyiv, Ukraine \\ T. Savka, Junior Researcher. Department of internal pathology pregnants, State Institution "Institute \\ of Pediatrics, Obstetrics and Gynecology named academic Elena M. Lukyanova of National Academy \\ of Medical Sciences of Ukraine" Kyiv, Ukraine
}

DOI: https://doi.org/10.31435/rsglobal_sr/30012021/7379

\section{ARTICLE INFO}

Received 29 November 2020

Accepted 17 January 2021

Published 23 January 2021

\section{KEYWORDS}

pregnancy, heart disease, low-molecular-weight heparin, warfarin, side effect, densitometry, osteopenia.

\begin{abstract}
The article presents data on the development of side effects from anticoagulant prophylaxis in pregnant women with diseases of the cardiovascular system. In particular, the anticoagulant effects on the skeletal system. Were studied the features of sonographic examination in this category of patients. The level of the main biomarkers of osteosynthesis and osteoresorption during pregnancy was studied. Were analyzed the influence of anticoagulants on the level of biomarkers of bone metabolism. Has been studied the relationship between densitometry data and calcitonin levels in pregnant women. The main aspects of the formation of osteopenic syndrome and osteoporosis in pregnant women with heart disease are considered. Has been studied the relationship between the clinical manifestations of osteopenic syndrome and the level of biomarkers of bone metabolism. Proposed the drug correction of the development of side effects due to anticoagulant thromboprophylaxis.
\end{abstract}

Citation: V. Medved, T. Savka. (2021) Condition of Bone Tissue in Pregnant Women with Diseases of the Cardiovascular System on the Background of Anticoagulant Prevention. Science Review. 1(36). doi: 10.31435/rsglobal_sr/30012021/7379

Copyright: (C) 2021 V. Medved, T. Savka. This is an open-access article distributed under the terms of the Creative Commons Attribution License (CC BY). The use, distribution or reproduction in other forums is permitted, provided the original author(s) or licensor are credited and that the original publication in this journal is cited, in accordance with accepted academic practice. No use, distribution or reproduction is permitted which does not comply with these terms.

Вступ. Вагітність сама по собі $є$ фактором ризику розвитку остеопорозу, що пов'язано із зміною метаболізму кальцію під час вагітності, зниженням його реабсорбції в нирках та підвищеними потребами кальцію, особливо в другу половину вагітності та під час лактації [1].

Епідеміологічні дані про частоту розвитку остеопороза серед жінок, які отримували під час вагітності антикоагулянти суттєво відрізняються в різних регіонах світу, що пояснюється різним соціально-економічним статусом та доступом до інструментальних методів діагностики остеопатичних змін. Так частота розвитку виявлення остеопатичних змін серед жінок, які отримували гепаринові антикоагулянти під час вагітності в країнах Північної Америки досягає майже $22 \%$, при цьому рівень компресійних переломів хребта протягом перших 10 років після пологів не досягає 4\%, тоді як в країнах Латинської Америки рівень компресійних переломів хребта, серед аналогічної групи жінок досягає майже $9 \%$, а показник діагностики остеопатичних змін під час вагітності становить менше 5\% [2]. 
Патогенез розвитку остеопорозу при тривалому використанні гепаринів $є$ недостатньо вивчений. Серед головних механізмів розвитку остеопорозу виділяють такі ефекти: пряма активація остеокластів, потенціювання активності колагенози та вплив на метаболізм вітаміна D [3].

Остеопатичні зміни виникають, зазвичай, при тривалому використанні гепаринів (понад 6 місяців). Розвиток даного ускладнення має прямий корелятивний зв'язок із тривалістю введення гепарину та його дозою Найчастіше остеопатичні зміни діагностують при тривалому використанні понад 15 тис. ОД нефракціонованого гепарину (НФГ) чи прийомі низько молекулярного гепарину (НМГ) в середніх профілактичних та терапевтичних дозах $[1,4]$.

Механізм розвитку остеопатичних змін при використанні в якості антикоагулянта антагоністів вітаміну К (варфарину) є широко вивченим, особливо тератогенний остеопатичний вплив. Встановлено, що тератогенний ефект варфарину виникає в першому триместрі з різною частотою. На ймовірність розвитку впливає доза препарату: ризик пропорційно збільшується при використанні понад 5мг на добу; та термін застосування: найбільший ризик розвитку вроджених вад розвитку в період з 6 по 12 тиждень гестації [5]. Найбільш описаним тератогенним синдромокомплексом варфаринотерапії $\epsilon$ Chondrodisplasia punctate, в основі розвитку якого лежить анамальний остеогенез та аномальний розвиток хрящової тканини [6]. Механізм розвитку даної патології полягає в пригніченні у-карбоксилювання остеокальцина - основного білка кісткової тканини, який синтезується остеокластами. Високі рівні остеокальцина в ембріона та екстраембріональних структурах свідчить про напруженість кісткового метаболізму, та саме цим обумовлений виражений негативний вплив варфарина на плід [7].

При тривалому (понад 3 місяці) прийомі варфарина в дозі 5 мг і більше на добу, аналогічний метаболічний ефект щодо кісткової тканини виникає і у матері. Це має велике значення в клінічній практиці, адже використання варфарину в дозі 5 мг $є$ частою практикою, оскільки така доза $є$ пограничною щодо тератогенного впливу та дозволена жінкам, які кормлять грудьми $[5,7]$.

Мета даного дослідження вивчити особливості обмінну кісткової тканини у пацієнток із захворюваннями серцево-судинної системи (ЗССС) на тлі антикоагулянтної профілактики венозного тромбоемболізму і на основі отриманих даних розробити диференційовані діагностичні та лікувально-профілактичні заходи, спрямовані на своєчасне виявлення та корекцію ускладнень вагітності, пологів й післяпологового періоду та побічних ефектів від проведеної антикоагуляції.

Матеріали та методи. Відповідно до поставлених мети і завдань нами проведено обстеження 140 вагітних із ЗССС, які отримували антикоагулянтну профілактику (АКП): 72 вагітних жінки із ЗССС (основна група) - застосовували запропоновану нами модифіковану АКП та комплексну терапію з першої половини вагітності; до групи порівняння увійшло 68 жінок із ЗССС, $з$ помірним та високим ступенями ризику розвитку венозного тромбоемболізму (BТЕ), які були скеровані на дообстеження, лікування та підготовку до пологів в ДУ «ІПАГ ім. акад. О.М. Лук'янової НАМН України» в терміні 34-38 тижнів вагітності, і відповідно отримували, до госпіталізації, лише стандартну АКП. Групу контролю склали 50 здорових вагітних жінок з низьким ризиком розвитку ВТЕ.

Основна група жінок отримувала окрім стандартної АКП запропоновану нами модифіковану терапію, яка включала: дезагрегантний препарат - ацетилсаліцилову кислоту в дозі 150мг 1 раз на добу перорально, після прийому їжі, 312 по 36 тиждень вагітності; комбінований препарат, який регулює обмін кальцію та фосфору в організмі - кальцій-D3, який містить в одній таблетці кальцію карбонат - 1250 мг, що еквівалентно 500 мг кальцію, холекальциферол (вітамін D3) - 10 мкг (400 MO) у вигляді концентрату холекальциферолу 4 мг, по 1 жувальній таблетці під час вечері, з 16 тижня вагітності до пологів; комбінований препарат, який покращує стан ендотелію, має протизапальний та фібринолітичний ефекти бетаргін, який містить в одному саше аргінін - 1000 мг та 1000 мг бетаїну, по 1 саше розчиненому в склянці (100 мл) питної води кімнатної температури двічі на добу після їжі. терапію.

Група порівняння жінок з ЗССС отримувала виключно стандартну антикоагулянтну

Для оцінки структурно-функціонального стану кісткової тканини використовували метод ультразвукової денситометрії за допомогою кількісного кісткового ультрасонометра Sahara (HologicInc., model 04874, 2008) на п’ятковій кістці. 
До переваг метода можна віднести широку доступність, низьку вартість, відсутність іонізуючого випромінювання для пацієнта. Останні клінічні дослідження вказують, що специфічність та інформативність ультразвукової денситометрії не поступається рентгенологічним методам визначення МЩКТ, і може рекомендуватись, як скринінговий метод для виявлення остеопенічних змін під час вагітності.

За допомогою сонографічної денситометрії визначали наступні показники: швидкість поширення ультразвуку через кістку (ШПУ, м/с), яка залежить від іiі щільності та еластичності; широкосмугове ослаблення ультразвукового сигналу (ШОУ, дБ/МГц), яке відображає не тільки щільність кісткової тканини, а й кількість, розміри та просторову орієнтацію трабекул; індекс міцності кісткової тканини (IM, \%), який вираховується комп'ютером на підставі показників ШПУ та ШОУ й відображає стан губчастої кісткової тканини пацієнта відносно категорії дорослих людей віком 20 років; Т-показник, який відображає, на яку частку середнього квадратичного відхилення відрізняється індекс міцності кісткової тканини пацієнта порівняно 3 умовно здоровими дорослими людьми віком 20 років; Z-показник, який відображає, на яку частку середнього квадратичного відхилення відрізняється індекс міцності кісткової тканини пацієнта порівняно з віковою нормою. Остеопороз діагностували за Т-критерієм при зниженні щільності кісткової тканини більше, ніж на $-2,5$ стандартного відхилення від показників умовно здорових 20-річних молодих дорослих людей, а остеопенію - при зниженні щільності кісткової тканини на -1,1-2,4 стандартного відхилення.

Дослідження концентрації метаболіту вітаміну D [25 (OH) D], рівнів остеокальцину та C-кінцевого телопептиду колагену I типа ( $\beta$-cross-laps, b-CTx) проводилось імуноферментним методом за допомогою аналізатора хемілюмінісцентного Architect i2000 SR, виробник «Abbott Laboratories».

Статистичну обробку даних проводили за допомогою пакета програми Microsoft Excel, SPSS- 14.0 for Windows. Для виявлення статистичної значущості відмінностей використовували непараметричний U-критерій Манна-Уїтні для незалежних змінних i критерій Стьюдента. Відмінності між аналізованими показниками вважали достовірними при рівні значимості $\mathrm{p} \leq 0,05$.

\section{Результати досліджень.}

Прийом антикоагулянтів серед обстежених пацієнток сприяв формуванню більш вираженого процесу ремоделювання в кістках, що призвело до достовірного зниження усіх показників міцності кісток за даними ультразвукової денситометрії порівняно 3 контрольною групою. При цьому середні значення T-критерію відповідали остеопенії, а Z-критерію - нормі (

Таблиця 1. Результати дослідження МЩКТ у обстежених пацієнток

\begin{tabular}{|l|c|c|c|}
\hline \multicolumn{1}{|c|}{ Показники денситометрії } & $\begin{array}{c}\text { Основна група } \\
(\mathrm{n}=72)\end{array}$ & $\begin{array}{c}\text { Група порівняння } \\
(\mathrm{n}=68)\end{array}$ & $\begin{array}{c}\text { Контрольна група } \\
(\mathrm{n}=50)\end{array}$ \\
\hline ШПУ, м/с & $1527,31 \pm 15,97 *$ & $15436,24 \pm 15,68 *$ & $1597,42 \pm 16,37$ \\
\hline ШОУ, дБ/МГц & $91,75 \pm 3,79 *$ & $92,18 \pm 3,85 *$ & $98,75 \pm 3,83$ \\
\hline ІМ, \% & $84,89 \pm 4,95 *$ & $83,56 \pm 4,37 *$ & $100,9 \pm 4,86$ \\
\hline $\begin{array}{l}\text { Частота виявлення } \\
\text { остеопенії, абс. (\%) }\end{array}$ & $28(38,9)^{*}$ & $26(38,2)^{*}$ & $2(4,0)$ \\
\hline $\begin{array}{l}\text { Частота виявлення } \\
\text { остеопорозу, абс. (\%) }\end{array}$ & $5(6,9) *$ & $4(5,9) *$ & 0 \\
\hline Т-критерій & $-0,84 \pm 0,05 *$ & $-0,87 \pm 0,06 *$ & $-0,21 \pm 0,05$ \\
\hline Z-критерій & $-0,25 \pm 0,07 *$ & $-0,24 \pm 0,08 *$ & $0,34 \pm 0,05$ \\
\hline
\end{tabular}

* - достовірна різниця 3 показниками контрольної групи, $\mathrm{p}<0,05$

Звертають на себе увагу, достовірні відмінності між показниками швидкість поширення ультразвуку через кістку (ШПУ) та широкосмуговим ослабленням ультразвукового сигналу (ШОУ) серед пацієнток із ЗССС та здоровими жінками. Так рівні ШПУ достовірно нижчі в основній групі $(1527,31 \pm 15,97)$ та групі порівняння $(15436,24 \pm 15,68)$ за аналогічний показник в контрольній групі (1597,42 16,37$)$. Рівень ШОУ серед вагітних КГ в середньому на 7-10\% вищий ніж у жінок з ОГ та ГП. Описані вище результати обстеження є непрямими ознаки, що свідчить про більш інтенсивні процеси резорбції в групах вагітних, які отримують антикоагулянти. 
На підставі наявності статистично значущих відмінностей в частоті формування остеопенії та остеопорозу і середніх значень показників кісткової міцності у вагітних, які отримують антикоагулянтну профілактику порівняно 3 жінками контрольної групи, можна дійти висновку про доцільність використання скринінгового дослідження п'яткової кістки методом ультразвукової денситометрії для виявлення зниження МЩКТ.

При проведенні оцінки впливу терапії на рівень показників ультразвукової денситометрії не було виявлено достовірної різниці між отриманими результати, про що свідчать дані, представлені в таблиці 2.

Таблиця 2. Показники денситометрії у обстежених пацієнток після проведеної терапії

\begin{tabular}{|l|c|c|}
\hline \multicolumn{1}{|c|}{ Показники денситометрії } & \multicolumn{1}{|c|}{$\begin{array}{c}\text { Основна група } \\
(\mathrm{n}=72)\end{array}$} & $\begin{array}{c}\text { Група порівняння } \\
(\mathrm{n}=68)\end{array}$ \\
\hline ШПУ, м/с & $1532,44 \pm 16,05$ & $1538,47 \pm 15,94$ \\
\hline ШОУ, дБ/МГц & $92,05 \pm 3,84$ & $92,08 \pm 3,81$ \\
\hline ІМ, \% & $83,76 \pm 4,88$ & $83,29 \pm 4,52$ \\
\hline $\begin{array}{l}\text { Частота виявлення остеопенії, } \\
\text { абс. (\%) }\end{array}$ & $28(38,9)$ & $26(38,2)$ \\
\hline $\begin{array}{l}\text { Частота виявлення остеопорозу, } \\
\text { абс. (\%) }\end{array}$ & $5(6,9)$ & $4(5,9)$ \\
\hline Т-критерій & $-0,82 \pm 0,04$ & $-0,85 \pm 0,05$ \\
\hline Z-критерій & $-0,26 \pm 0,07$ & $-0,25 \pm 0,08$ \\
\hline
\end{tabular}

* - достовірна різниця з показниками контрольної групи, $\mathrm{p}<0,05$

Відсутність достовірної різниці між отриманими результатами свідчить про низьку прогностичну цінність сонографічної денситометрії при оцінці ефективності проведення медикаментозної корекції метаболізму кісткової тканини.

3 метою дослідження вираженості остеопенічного синдрому у вагітних із ЗССС, які отримували АКП було досліджено рівень кальцитоніну.

При дослідженні рівня кальцитоніну серед обстежених жінок було встановлено достовірно нижчі показники серед пацієнток із ЗССС, в порівнянні із жінками 3 групи контролю. Так, дефіцит кальцитоніну було встановлено у $6(8,3 \%)$ вагітних основної групи та у $6(8,8 \%)$ жінок групи порівняння. Субоптимальний рівень виявлено у $28(38,9 \%)$ і $25(36,8 \%)$ пацієнток основної групи та групи порівняння відповідно, та у 6 (12,0\%) вагітних контрольної групи. Отримані результати наведено в таблиці 3.

Таблиця 3. Концентрація кальцитоніну у обстежених пацієнток (нг/мл), абс. (\%)

\begin{tabular}{|l|c|c|c|}
\hline \multicolumn{1}{|c|}{ Рівень кальцитоніну } & ОГ & ГП & КГ \\
\hline Дефіцит (<20 нг/мл) & $6(8,3) *$ & $6(8,8) *$ & 0 \\
\hline $\begin{array}{l}\text { Субоптимальний рівень } \\
(21-30 \text { нг/мл) }\end{array}$ & $28(38,9) *$ & $25(36,8) *$ & $6(12,0)$ \\
\hline $\begin{array}{l}\text { Оптимальний рівень }(31- \\
50 \text { нг/мл) }\end{array}$ & $38(52,3) *$ & $37(54,4) *$ & $44(88,0)$ \\
\hline
\end{tabular}

* - достовірна різниця з показниками контрольної групи, $\mathrm{p}<0,05$

Нами було виявлено прямий кореляційний зв'язок між отриманими результатами по рівню кальцитоніну і показниками ультразвукової денситометрії. Так дефіцит кальцитоніну (<20 нг/мл) було виявлено серед жінок у яких показники денситометрії свідчили про остеопороз. У пацієнток з остеопенічними показниками МЩКТ рівень кальцитоніну був в субоптимальних межах.

Середній рівень концентрації кальцітонину в плазмі крові, у обстежених вагітних становив: в основний групі - 28,7 нг/мл, в групі порівняння - 27,9 нг/мЛ та 39,4 нг/мл в групі конролю (рисунок 1). 


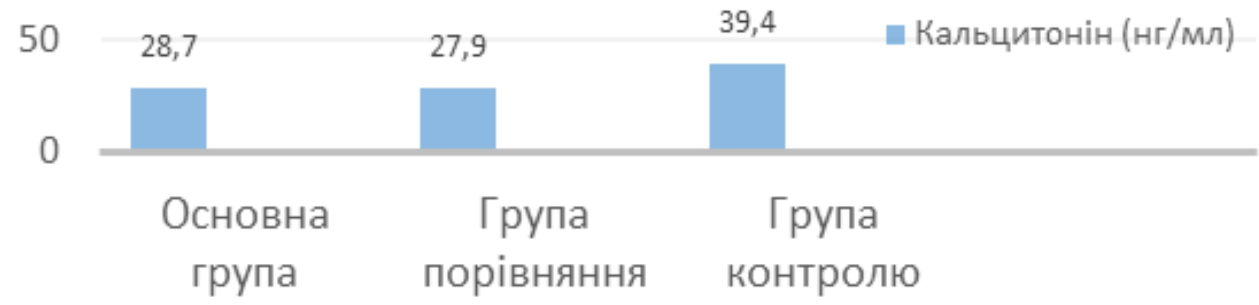

Рис. 1. Середній рівень кальцитоніну в групах обстежених жінок

При аналізі клінічного перебігу вагітностей, було встановлено прямий кореляційний зв'язок між клінічними проявами остеопенічного синдрому та рівнем кальцитоніну. В таблиці 4 наведено клінічні симптоми остеопенічного синдрому, які було виявлено у обстежених пацієнток.

Таблиця 4. Симптоми остеопенічного синдрому серед обстежених пацієнток, абс. (\%)

\begin{tabular}{|c|c|c|c|}
\hline Симптом & $\mathrm{O \Gamma}$ & ГП & КГ \\
\hline Міалгія & $19(27,1) * \wedge$ & $17(25,0)^{\wedge}$ & $3(6,0)$ \\
\hline Симфізіопатія & $9(12,5) *$ & $9(13,2)$ & - \\
\hline Симфізит & $2(2,8)$ & $2(2,9)^{\wedge}$ & $1(2,0)$ \\
\hline Сакроілеопатія & $1(1,4)$ & $1(1,5)$ & - \\
\hline Кокцигодинія & $1(1,4)$ & $1(1,5)$ & - \\
\hline Люмалгія & $1(1,4)$ & $1(1,5)$ & - \\
\hline Люмбалішіалгія & $1(1,4)$ & $1(1,5)$ & - \\
\hline Поєднання декількох симптомів & $6(8,3) *$ & $5(7,4)$ & - \\
\hline
\end{tabular}

Найбільш частими клінічними проявами остеопенічного синдрому були міалгія та симфізіопатія. Частота розвитку міалгії була наступною: $19(27,1 \%)$ - в основній групі, $17(25,0)$ - в групі порівняння та $3(6,0 \%)$ серед жінок групи контролю. Симфізіопатію було діагностовано у $9(12,5 \%)$ пацієнток основної групи та $9(13,2 \%)-$-групи порівняння. Варто зауважити, що серед пацієнток, у яких було виявлено зниження МЩКТ, яке свідчило про остеопороз, та у пацієнток із дефіцитом кальцитоніну було встановлено поєднання міалгії 3 іншими симптомами остеопатичного синдрому. Даний факт дає можливість зробити висновок, що наявність міалгії у вагітних можна розглядати, як ранню ознаку розвитку остеопатії.

При оцінці впливу проведеної корекції терапії на рівень кальцитоніну в плазмі крові жінок із ЗССС, які отримували АКП, ми спостерігали достовірне зростання рівня даного показника, про що свідчать дані наведені на рисунку 2. Необхідність проведення корекції терапії підтверджується ще і даними отриманими в групі порівняння, які ілюструють подальше зменшення рівня кальцитоніну.

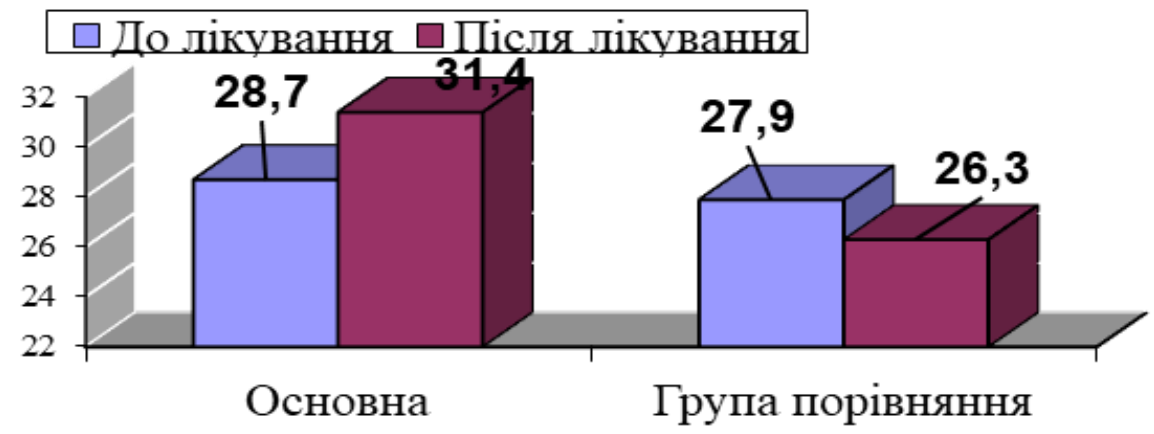

Рис. 2. Конщентрація кальцитононіну (нг/мл) до та після лікування. 
Отриманні дані вказують на позитивний ефект проведеної корекції терапії на показники метаболізму в кістковій тканині, зокрема середній рівень кальцитоніну у жінок в основній групі виріс на 9,4\% (з 28,7 нг/мл до 31,4 нг/мл).

Запропонована нами корекції терапії мала позитивний вплив на клінічний перебіг остеопенічного синдрому серед жінок основної групи. Так частота розвитку міалгії знизилась на $36,8 \%$ (з 19 до 12 випадків), а прояви симфізіопатії купійовано у 5 пацієнток, що дало можливість знизити частоту даного симптому на 44,4\% - 39 до 4 випадків (рис. 3 ).

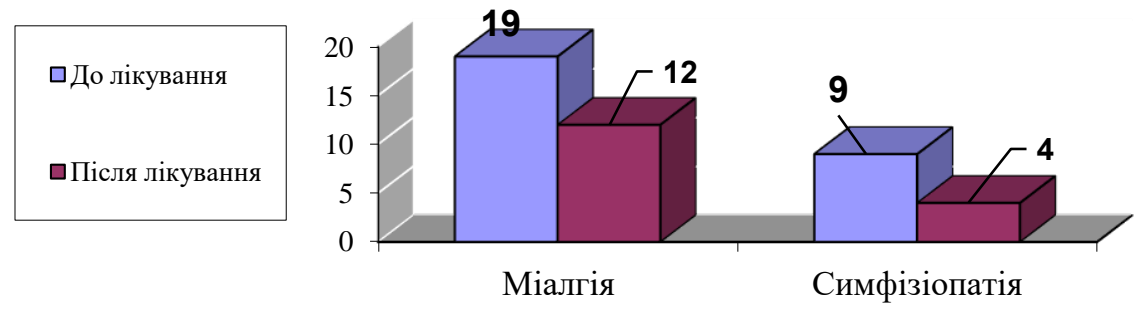

Рис. 3. Частота розвитку симптомів остеопенічного синдрому до та після проведеної корекиії терапії.

Ультразвукові методи визначення якості кісткової тканини мають важливе значення для клінічної оцінки пацієнтів з остеопенією, але, будучи статичними параметрами, не дають об'єктивної інформації щодо активності ії метаболізму. На відміну від даних сонографії, біохімічні показники є динамічними в оцінці стану скелета, дозволяючи визначити баланс між утворенням кісткової тканини і процесами резорбції. Окрім того, не зважаючи на високу достовірність, денситометрична оцінка ефективності терапії можлива лише через 9-12 місяців від початку терапії, в той час як біохімічні маркери дозволяють провести дану оцінку через 2-3 місяці. Враховуючи доведений вплив антикоагулянтів на процеси метаболізму в кістковій тканині, а також встановлені, у багатьох дослідженнях, кореляційні зв'язки біомаркерів 3 мінеральною щільністю кісткової тканини, відкриваються широкі перспективи щодо впровадження їх дослідження в клінічну практику.

Одними з найбільш чутливих показників обміну кісткової тканини є остеокальцин (Ок) - маркер остеосинтезу, та C-кінцевий телопептид колагену I типа ( $\beta$-cross-laps, b-CTx) - маркер активності остеокластів.

При аналізі концентрації Ок в плазмі венозної крові у вагітних із ЗССС, які отримували АКП, зниження його рівня виявлялося у $26(36,1 \%)$ і $25(36,7 \%)$ пацієнток основної групи та групи порівняння відповідно. У вагітних контрольної групи зниження рівня Ок виявлено лише в 2 випадках (4 \%), при цьому воно носило незначний характер. При дослідженні середнього рівня Ок в групах виявлено, що він статистично мав більші величини у вагітних, які мали ЗССС, у порівнянні з контрольною $(\mathrm{p}<0,05)$, однак, при цьому, дане зростання не досягало критичних значень, і в цілому не було більшим позначки в 29,5 нг/мл. Середній рівень Ок у

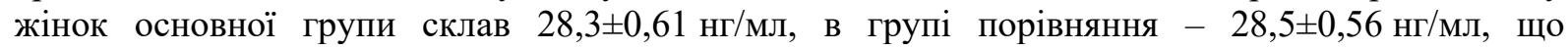
достовірно були вищими за показники у вагітних жінок групи контролю $(22,5 \pm 0,62$ нг/мл). Така тенденція пов'язана із більш інтенсивними процесами репаративного остеосинтезу серед пацієнток, які отримували АКП. Дані представлені на рисунку 4.

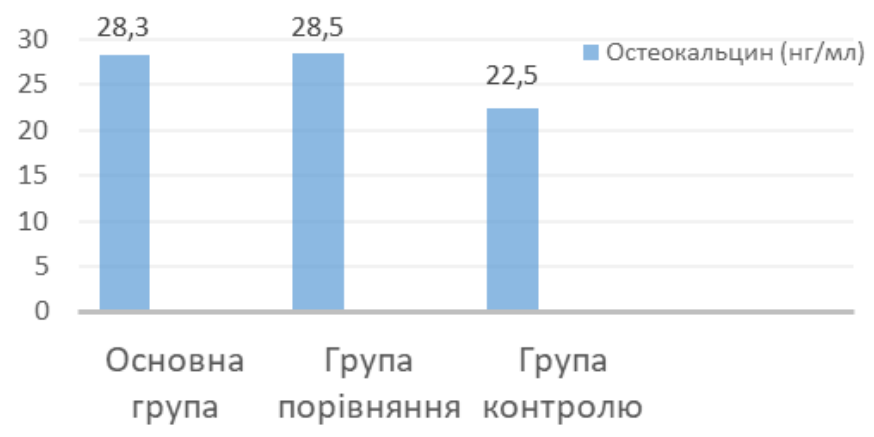

Рис. 4. Концентраиія остеокальичину в групах дослідження 
У вагітних жінок із ЗССС, які отримували АКП, було виявлено достовірно більш високий вміст С-кінцевого телопептиду колагену І-го типу, в плазмі крові, в порівнянні 3 групою контролю, це підвищення в цілому носило виражений характер (рис. 5). Так в основній групі вміст b-CTx був підвищений в $31(43,0 \%)$ випадках, і становив в середньому $1,42 \pm 0,17$ нг/мл. У групі порівняння у вагітних з ЗССС, які отримували АКП, концентрація bСТх була підвищена у 30 (44,1\%) пацієнток, і становила в середньому по групі $1,57 \pm 0,18$ нг/мл. Водночас у групі контролю дані показники склали $0,52 \pm 0,13$ нг/мл, i підвищення відзначалося лише у 2 (4 \%) вагітних $(\mathrm{p}<0,05)$.

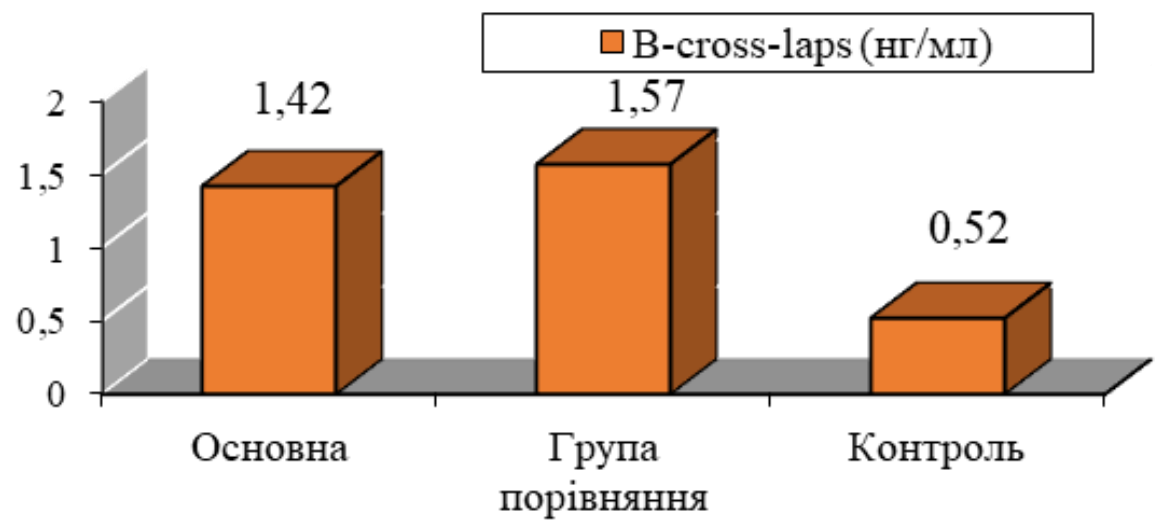

Рис. 5. Концентрачія b-СТх в групах дослідження

Грунтуючись на отриманих даних можна припустити, що використання антикоагулянтів під час вагітності призводить до розвитку дисбалансу між процесами резорбції та остеосинтезу, що стає причиною зниження мінералізації кісткової тканини у вагітних.

Аналіз маркерів метаболізму кісткової тканини виявив підвищення активності резорбтивних процесів на фоні інтенсивного остеосинтезу. Дані зміни носили клінічно значущий характер, і піддавалися корекції. Це узгоджується з даними інших дослідників про пряму залежність ступеня остеопенії від рівнів Ок і b-CTх.

Нами проведено оцінку маркерів метаболізму остеоцитів Ок та b-CTx в плазмі венозної крові у вагітних із ЗССС обох досліджуваних груп після проведеного лікування. Середній вміст b-CTx знизився в 1,6 разів і склав $0,87 \pm 0,12$ нл/мл в основній групі та лише в 0,9 разів у групі порівняння і склав 1,41 \pm 0,14 нл/мл відповідно. Дані представлені на рисунку 6.

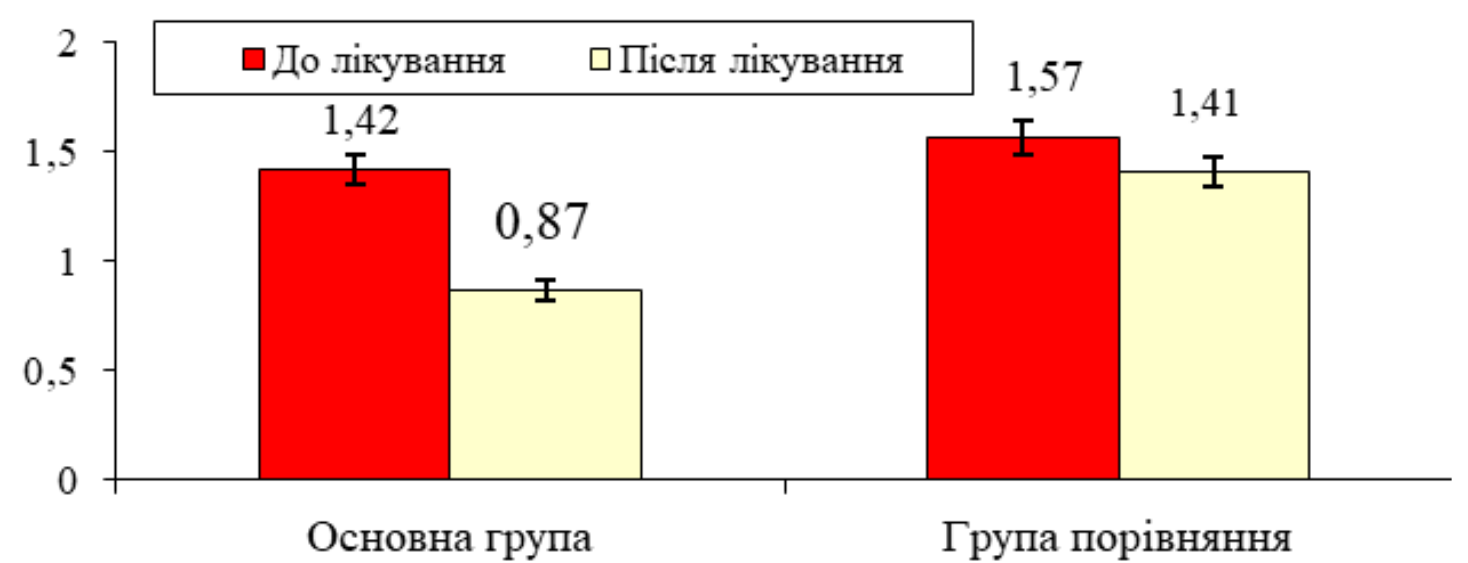

Рис. 6. Концентрація $b$-CTx (нг/мл) в групах дослідження до та після лікування

При проведенні оцінки впливу терапії на рівень Ок в плазмі крові у жінок із ЗССС, які отримували АКП, ми спостерігали достовірне зростання рівня даного показника, про що свідчать дані, представлені на рисунку 7. 


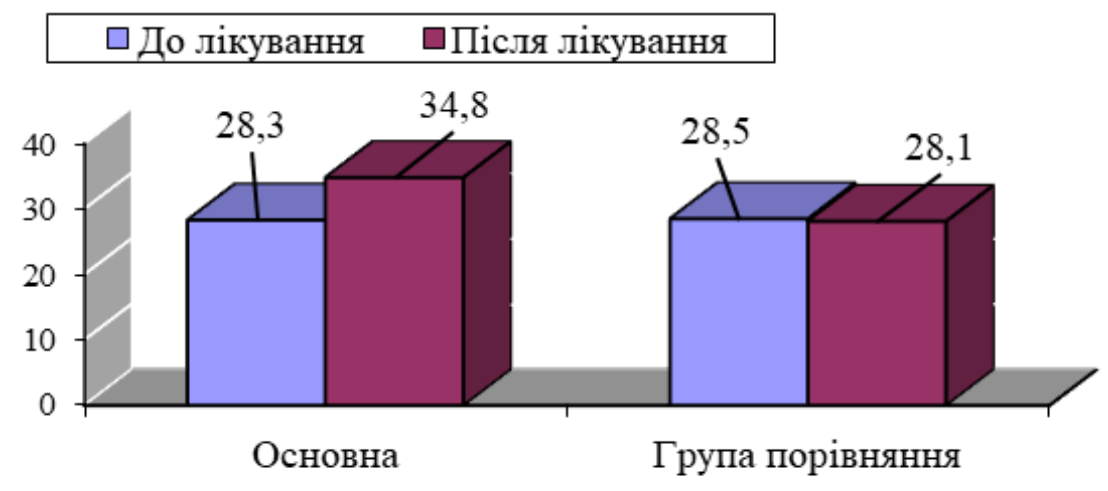

Рис. 7. Концентрація Ок (нг/мл) в групах дослідження до та після лікування

Як видно із представлених даних, середній рівень Ок у жінок з ЗССС, які отримували АКП, після проведеної запропонованої нами комплексної терапії виріс на 23,1\% порівняно 3 вихідними даними і склав $34,8 \pm 0,43$ нг/мл. Вміст остеокальцину в плазмі крові жінок, що отримували традиційне лікування, не мав вираженої тенденції до зростання, проте його рівень залишився фактично без змін $-28,1 \pm 0,42$ нг/мл.

Таким чином, ми виявили у вагітних жінок із ЗССС, які отримували АКП, статистично достовірно нижчі показники остеосинтезу, на фоні вищих показників остеорезорбції (b-CTx), в порівнянні з групою контролю. Зниження рівня b-CTx в 1,6 разів та збільшення Ок в плазмі крові на $23,1 \%$ свідчить про позитивний стабілізуючий вплив запропонованої нами комплексної терапії на метаболічні процеси в кістковій тканині.

Обговорення результатів. Отриманні результати обстеження свідчить про більш інтенсивні процеси резорбції у вагітних, які отримують антикоагулянти.

Визначення МЩКТ методом ультразвукової денситометрії є ефективним скринінговим методом, під час вагітності, для виявлення остеопенічних змін. Однак даний метод має низьку прогностичну цінність щодо оцінки ефективності проведення медикаментозної корекції метаболізму кісткової тканини.

Нами було виявлено прямий кореляційний зв'язок між отриманими результатами по рівню кальцитоніну і показниками ультразвукової денситометрії та клінічними проявами остеопенічного синдрому.

Найбільш частим клінічним проявом остеопенічного синдрому серед обстежених жінок була міалгія та симфізіопатія. Міалгія є раннім клінічним проявом остеопатичного синдрому, а його купування напряму відображало ефективність медикаментозної корекції.

Зниження частоти розвитку міалгії на $36,8 \%$ та симфізіопатії на $44,4 \%$ демонструє ефективність запропонованої нами комплексної терапії.

При аналізі рівнів біомаркерів метаболізму кісткової тканини виявилено статистично достовірно нижчі показники остеосинтезу, на фоні вищих показників остеорезорбції. Зниження рівня b-CTx в 1,6 разів та збільшення Ок в плазмі крові на $23,1 \%$ свідчить про позитивний стабілізуючий вплив запропонованої нами комплексної терапії на метаболічні процеси в кістковій тканині.

\section{Висновки.}

1. Проведення тривалої антикоагулянтної профілактики під час вагітності має негативний ефект на процеси метаболізму в кістковій тканині.

2. Денситометрія $є$ ефективним скринінговим методом виявлення остеопенічних змін у вагітних, однак даний метод не підходить для контролю за ефективністю проведення корекції.

3. Зниження клінічних проявів остеопенічного синдрому та покращення показників біомаркерів метаболізму кісткової тканини свідчить про позитивний ефект запропонованої нами терапії.

4. Враховуючи високу частоту розвитку остеопенічного синдрому серед вагітних із захворюваннями серцево-судинної системи, які тривало отримують антикоагулянти, 3 метою розробки профілактичних заходів, виникає необхідність подальшого вивчення даної проблеми.

Автори статті повідомляють про відсутність потенційного конфлікту інтересів. 


\section{ЛIТЕРАТУРА}

1. Shriraam Mahadevan, V Kumaravel, R Bharath (2012) Calcium and bone disorders in pregnancy. Indian J Endocrinol Metab. 2012 May;16(3):358-63. doi: 10.4103/2230-8210.95665.

2. P. Galambosi et al. (2016) Prolonged low-molecular-weight heparin use during pregnancy and subsequent bone mineral density. Thromb Res. 2016 Jul;143:122-6. doi: 10.1016/j.thromres.2016.05.016. Epub 2016 May 19.

3. Hardcastle SA, Yahya F, Bhalla AK (2019) Pregnancy-associated osteoporosis: a UK case series and literature review. Osteoporos Int. 2019 May;30(5):939-948. doi: 10.1007/s00198-019-04842-w. Epub 2019 Jan 23.

4. E. Lefkou et al. (2010) Review: low-molecular-weight heparin-induced osteoporosis and osteoporotic fractures: a myth or an existing entity? J. Lupus 2010 Jan;19(1):3-12. doi: 10.1177/0961203309353171. Epub 2009 Nov 24.

5. Salvatore Santo Signorelli et al. (2019) Anticoagulants and Osteoporosis. Int J Mol Sci. 2019 Nov; 20(21): 5275. Published online 2019 Oct 24. doi: 10.3390/ijms20215275

6. Diana M Sobieraj et al. (2012) Comparative effectiveness of low-molecular-weight heparins versus other anticoagulants in major orthopedic surgery: a systematic review and meta-analysis. J. Pharmacotherapy. 2012 Sep;32(9):799-808. doi: 10.1002/j.1875-9114.2012.01106.x. Epub 2012 Jun 28.

7. A Kapoor et al. (2017) Comparative effectiveness of venous thromboembolism prophylaxis options for the patient undergoing total hip and knee replacement: a network meta-analysis. J Thromb Haemost. 2017 Feb;15(2):284-294. doi: 10.1111/jth.13566. Epub 2017 Jan 19. 